\title{
Promoting cross-border knowledge transfer for new product development in MNCs: a process view
}

\author{
Yang Liu ${ }^{1}$
}

Published online: 27 July 2017

(C) The Author(s) 2017. This article is an open access publication

\begin{abstract}
Cross-border knowledge transfer plays an important role in the competitive advantage of multinational corporations (MNCs). However, it can be quite challenging due to cultural differences and lack of trust between organizational units located in different countries. Prior studies have not explored the knowledge transfer process (and its key nodes) in new product development in MNCs. This research aims to understand this process focusing on how knowledge transfer can be promoted through trust and understanding of cultural traits. A qualitative single-case study of an automotive MNC was conducted. I found that for the key nodes of the process, the company leveraged different mechanisms to promote knowledge transfer. These mechanisms facilitated trust and understanding of cultural traits. Headquarters provided key administrative support for these mechanisms. This study contributes to the literature through proposing a process view showing how knowledge transfer can be promoted by different mechanisms in different nodes of the process. In addition, insights were drawn on how to manage trust and the cultural difference across countries.
\end{abstract}

Keywords Knowledge transfer $\cdot$ New product development $\cdot$ Multinational corporations $\cdot$ Trust $\cdot$ Cultural traits

JEL Classification F23 - M16 - O32

\section{Introduction}

Cross-border knowledge transfer (i.e. movement of knowledge from one country to another) is the key to competitive advantage for multinational corporations (MNCs) (Kasperet al. 2013; Kotabeet al. 2007; Monteiroet al. 2008; Schlegelmilch and Chini

Yang Liu

yang_liu2011@yahoo.com

1 Management School, Queen's University Belfast, Riddel Hall, 185 Stranmillis Road, Belfast BT9 5EE, UK 
2003). However, lack of trust and cultural differences are believed to be key barriers to effective knowledge transfer across borders (Ghoshal and Bartlett 1988; Subramaniam 2006; Tavcaret al. 2005). Trust and understanding of cultural traits affect the motivational disposition to share knowledge (Sarala and Vaara 2010), which is the key to effective knowledge transfer (Gupta and Govindarajan 2000). MNCs have the subsidiaries dispersed globally (Bartlett and Ghoshal 2000). Research has shown that geographical distance between organizational units could negatively affect trust between members (Castellanoet al. 2017; Ghemawat 2001; Haas and Cummings 2015). Cultural differences have a similar effect as barriers of mutual understanding.

This study explores knowledge transfer in the new product development (NPD) context. The NPD context is quite relevant to knowledge transfer due to its nature of crossfunctional collaboration involving, for example, R\&D, marketing, and production (Ulrich and Eppinger 2012). For MNCs, there are bigger challenges in NPD projects. They need to leverage globally dispersed knowledge, such as technical knowledge and market knowledge, produced by different functions to develop products with better quality and lower costs while appealing to local customers in different countries (Monplaisiret al. 2009; Subramaniamet al. 1998). Therefore, managing cross-border knowledge transfer effectively is critical for high NPD performance in MNCs.

Prior studies on knowledge transfer have been predominantly static identifying and testing the factors affecting knowledge transfer (Cavaliereet al. 2015; Gupta and Govindarajan 2000; Li 2005). Research in this area has called for more studies adopting a process view (Michailova and Bernhard Nielsen 2006). A process view can offer insights on how certain mechanisms for promoting knowledge transfer unfold. In the NPD context, knowledge transfer is constantly needed throughout NPD projects (Ulrich and Eppinger 2012), which forms a knowledge transfer process. As the activities differ across NPD phases, the mechanism for promoting knowledge transfer may need to be altered. Exploring cross-border knowledge transfer as a process in NPD in MNCs could be especially rewarding due to the global dispersion of different functions. However, it has not been well addressed in prior studies. Hence, I propose the research questions as below.

RQs: How can MNCs promote knowledge transfer across borders in NPD through enhancing trust and understanding of cultural traits? How can the mechanisms differ across nodes of the knowledge transfer process?

To answer the research questions, I conducted a qualitative single-case study of CarInc. Through analyzing the knowledge transfer process in NPD in CarInc, I found that the firm leveraged different mechanisms to promote knowledge transfer, namely, inclusive thinking, internal competition, technical capability, and standardization. Headquarters offered critical administrative support to realize these mechanisms. This study contributes to knowledge transfer research by revealing the alternating nature of mechanisms along the key nodes of the knowledge transfer process in MNCs.

The remainder of the paper is structured as follows. Section 2 presents the theoretical background on cross-border knowledge transfer, trust and cultural differences in MNCs, and the NPD context. Section 3 presents the methods for the qualitative single-case study to analyze the knowledge transfer process in NPD of CarInc. Section 4 presents the research findings. Section 5 discusses the theoretical contributions and managerial implications of the study. 


\section{Theoretical background}

\subsection{Cross-border knowledge transfer in MNCs}

MNCs can leverage talents and knowledge in the worldwide scope. Such cross-border knowledge transfer is the key to the competitive advantage of MNCs (Anderssonet al. 2016; Kasperet al. 2013; Michailova and Bernhard Nielsen 2006; Scaleraet al. 2014). For MNCs, local knowledge is transferred through cross-border cooperation and communication. However, a lot of challenges remain, such as tacitness of overseas knowledge (Bjorkmanet al. 2004; Subramaniam and Venkatraman 2001) and communication barrier in global teams (Sosaet al. 2002). Communication barrier can be caused by lack of trust and cultural differences across organizational units globally.

Priors studies have indicated factors that can affect the effectiveness of cross-border knowledge transfer in MNCs. One important factor is organizational culture (Appeldorn 1997; Cavaliere and Lombardi 2015; Hong and Nguyen 2013). In a context of greater cooperation climate, global team members are more willing to listen to others and compromise, thus conflicts are avoided (Subramaniam 2006). Team co-location can also affect knowledge transfer, because some knowledge is tacit, deep-rooted in people's head, and can be more easily leveraged through face-to-face communication (Noorderhaven and Harzing 2009; Subramaniam and Venkatraman 2001). However, large-scale co-location is difficult to implement in practice because it is time-consuming and costly (Kahn and McDonough 1997; Rafii 1995). Therefore, MNCs often need to use information technology (IT) tools such as teleconferencing and management information systems for global knowledge transfer. It is shown that the IT infrastructure can enhance the firms' capability to leverage globally dispersed knowledge, therefore, leads to higher NPD performances (Kleinschmidtet al. 2010). To leverage tacit overseas knowledge, increasing the frequency of communication would be helpful (Subramaniam and Venkatraman 2001), especially face-to-face communication (Bierly et al. 2009), but too much communication can reduce creativity (Tavcaret al. 2005).

\subsection{Trust and cultural difference in MNCs}

Among numerous factors affecting cross-border knowledge transfer, two critical ones are trust and cultural differences across organizational units globally. They can affect organizational members' motivational disposition to share knowledge with others (Sarala and Vaara 2010). Prior studies have found that trust can explain the level and quality of knowledge sharing (van Dijket al. 2016). More studies have been conducted to understand the trust between organizational members. Buckleyet al. (2006) argue that trust comprises technical trust and personal trust. Technical trust denotes confidence in the technical capability of other organizational members/units. Personal trust is a belief by one party that the other party will not pursue its interests at the cost of this party (Reagans and McEvily 2003). Dhanarajet al. (2004) indicate that trust signifies a commitment by organizational members which leads to better collaboration results, as it functions as a social control mechanism. They also argue that reputation can facilitate trust.

Organizational members in different countries show different cultural traits (e.g. different work habits). Trust and cultural traits are interrelated, according to prior studies. Cultural differences could prevent effective communication and mutual understanding, thus undermining trust. Sarala and Vaara (2010) argue that people tend to view 
organizational members in a different culture as out-group members who are less trustworthy. To overcome the challenge, MNCs made efforts as revealed by studies. Javidanet al. (2005) indicate that understanding of common cultural traits and common goals across organizational members contribute to trust. Related, Li (2005) suggests that trust can facilitate fully committed coordination and collaboration, which enhances understanding of cultural traits between organizational members.

Research in human resource management (HRM) has shed some light on knowledge transfer in MNCs. Minbaeva (2005) focuses on knowledge receivers and argues that HRM practices of staffing, performance appraisal, reward systems, and career management can enhance absorptive capacity, and thus knowledge transfer. These HRM practices could affect intrinsic and extrinsic motivation of knowledge receivers (Minbaeva 2008). Bjorkmanet al. (2004) focus on knowledge senders and show that MNC headquarters could promote knowledge transfer through performance evaluation criteria, subsidiary management compensation, and expatriate managers. Both senders and receivers should commit to knowledge transfer in order for it to be effective (Taschler and Chappelow 1997). However, while many studies have focused on absorptive capacity (Minbaeva 2007; Minbaevaet al. 2003), much less research has focused on trust and understanding of cultural traits. Therefore, it is still not quite clear how HRM practices can enhance trust and understanding of cultural traits for knowledge transfer in MNCs. This study covers this issue, as I will show how MNC headquarters provide administrative support through HRM practices.

\subsection{The new product development context}

The NPD context is highly relevant to knowledge transfer. Studies show the cross-functional nature of the NPD activities (Hollandet al. 2000; Salomoet al. 2010). NPD activities involve not only the R\&D department, but also marketing, production, purchasing, and finance functions (Eppinger and Chitkara 2006; Ulrich and Eppinger 2012). It is suggested that cross-functional collaboration which facilitates knowledge transfer is the key to successful NPD (Hollandet al. 2000). However, there are challenges of knowledge transfer in NPD. For example, research in R\&D-marketing integration reveals the difficulties of integration including miscommunication, lack of trust, and different thinking perspectives (Shermanet al. 2005; Songet al. 1996). These difficulties are largely due to the specialization of functions, different functional objectives, and different knowledge structures (Carlile 2002; Moenaert and Souder 1990; Souder 1988).

MNCs would face even bigger challenges on cross-national cooperation in NPD in that each subsidiary (with a certain function) has a different local context (McDonough et al. 2001). Geographical distance leads to difficulty of communication and lack of trust of team members in different countries (Barczak and McDonough 2003; McDonough et al. 2001), besides barriers caused by different functions.

\subsection{Cross-border knowledge transfer as a process in NPD}

New product development is composed of a sequence of activities that start from identifying market opportunities to production, sale, and delivery of a product (Ulrich and Eppinger 2012). Although with variations, prior studies largely support that there are five phases of NPD: planning, concept development, product engineering, testing, and trial production and market launch (Clark and Fujimoto 1991; Cooper and Kleinschmidt 1986; Eppinger and Chitkara 2006; Karagozoglu and Brown 1993; Schilling and Hill 1998; Song 
and Parry 1997). Across these phases, it starts from abstract product ideas to concrete and reliable products on the market.

As knowledge transfer happens throughout NPD, it can be regarded as a process. Because there are different activities in different phases of NPD, knowledge transfer activities and promoting mechanisms are likely to differ along the process. These phases of NPD, therefore, denote key nodes of the knowledge transfer process. Based on the literature in NPD (Clark and Fujimoto 1991; Cooper and Kleinschmidt 1986; Ulrich and

Table 1 Knowledge transfer as a process in NPD

\begin{tabular}{|c|c|c|c|c|c|}
\hline Phase & $\begin{array}{l}\text { Product } \\
\text { planning }\end{array}$ & $\begin{array}{l}\text { Concept } \\
\text { development }\end{array}$ & $\begin{array}{l}\text { Product } \\
\text { engineering }\end{array}$ & Product testing & $\begin{array}{l}\text { Trial production } \\
\text { and market } \\
\text { launch }\end{array}$ \\
\hline $\begin{array}{l}\text { Main } \\
\text { objectives }\end{array}$ & $\begin{array}{l}\text { Generate } \\
\text { product ideas } \\
\text { and initiate } \\
\text { an NPD } \\
\text { project }\end{array}$ & $\begin{array}{l}\text { Generate } \\
\text { product } \\
\text { concepts } \\
\text { (with } \\
\text { drawings) } \\
\text { and select } \\
\text { from the } \\
\text { concepts to } \\
\text { develop }\end{array}$ & $\begin{array}{l}\text { Conduct } \\
\text { system-level } \\
\text { design and } \\
\text { component } \\
\text { design for } \\
\text { products }\end{array}$ & $\begin{array}{l}\text { Test and refine } \\
\text { the product } \\
\text { design to } \\
\text { ensure it } \\
\text { works } \\
\text { properly and } \\
\text { meets legal } \\
\text { requirements }\end{array}$ & $\begin{array}{l}\text { Make sure that } \\
\text { products can } \\
\text { be produced } \\
\text { properly and } \\
\text { launch } \\
\text { products in } \\
\text { the market }\end{array}$ \\
\hline $\begin{array}{l}\text { Main } \\
\text { activities }\end{array}$ & $\begin{array}{l}\text { Identify } \\
\text { opportunities } \\
\text { and generate } \\
\text { ideas } \\
\text { Identify } \\
\text { customers } \\
\text { and market } \\
\text { size } \\
\text { Conduct } \\
\text { business case } \\
\text { analysis and } \\
\text { market } \\
\text { research } \\
\text { Define project } \\
\text { and prepare } \\
\text { documents } \\
\text { Identify project } \\
\text { timing, } \\
\text { resources, } \\
\text { and capital }\end{array}$ & $\begin{array}{l}\text { Generate } \\
\text { product } \\
\text { concepts } \\
\text { Select product } \\
\text { concepts } \\
\text { Test product } \\
\text { concepts } \\
\text { Refine the } \\
\text { business case }\end{array}$ & $\begin{array}{l}\text { Define product } \\
\text { architecture } \\
\text { Define part } \\
\text { geometry } \\
\text { Choose } \\
\text { materials } \\
\text { Freeze hardware } \\
\text { and software } \\
\text { design } \\
\text { Make bill of } \\
\text { material } \\
\text { Complete } \\
\text { engineering } \\
\text { documentation }\end{array}$ & $\begin{array}{l}\text { Build prototypes } \\
\text { Conduct } \\
\text { reliability } \\
\text { testing and life } \\
\text { testing } \\
\text { Apply for } \\
\text { regulatory } \\
\text { approval } \\
\text { Refine product } \\
\text { design }\end{array}$ & $\begin{array}{l}\text { Identify } \\
\text { production } \\
\text { issues and } \\
\text { modify } \\
\text { products } \\
\text { when } \\
\text { necessary } \\
\text { Train the } \\
\text { workforce in } \\
\text { the plants } \\
\text { Finalize product } \\
\text { specifications } \\
\text { Finalize the } \\
\text { launch plan }\end{array}$ \\
\hline $\begin{array}{l}\text { Main types } \\
\text { of } \\
\text { knowledge } \\
\text { transferred }\end{array}$ & $\begin{array}{l}\text { Market } \\
\text { knowledge-_- } \\
\text { Market } \\
\text { requirements } \\
\text { and product } \\
\text { ideas }\end{array}$ & $\begin{array}{l}\text { Technical and } \\
\text { market } \\
\text { knowledge- } \\
\text { Conceptual } \\
\text { design }\end{array}$ & $\begin{array}{l}\text { Technical } \\
\text { knowledge- } \\
\text { system and } \\
\text { components } \\
\text { design }\end{array}$ & $\begin{array}{l}\text { Technical } \\
\text { knowledge- }- \\
\text { Detailed } \\
\text { product design } \\
\text { and testing } \\
\text { results }\end{array}$ & $\begin{array}{l}\text { Technical } \\
\text { knowledge- } \\
\text { Product } \\
\text { specifications } \\
\text { and detailed } \\
\text { design }\end{array}$ \\
\hline $\begin{array}{l}\text { Main } \\
\text { functions } \\
\text { involved in } \\
\text { knowledge } \\
\text { transfer }\end{array}$ & $\begin{array}{l}\text { R\&D and } \\
\text { marketing }\end{array}$ & $\begin{array}{l}\text { R\&D and } \\
\text { industrial } \\
\text { design } \\
\text { centers }\end{array}$ & $\begin{array}{l}\text { R\&D teams/ } \\
\text { units }\end{array}$ & $\begin{array}{l}\text { R\&D and testing } \\
\text { centers }\end{array}$ & $\begin{array}{l}\text { R\&D, } \\
\text { production, } \\
\text { and marketing }\end{array}$ \\
\hline
\end{tabular}


Eppinger 2012), Table 1 shows NPD activities, types of knowledge, and functions involved in each node of the process.

There are abundant studies identifying the factors affecting knowledge transfer, but mainly with a static view. Very few studies have adopted a process view to reveal the dynamics of knowledge transfer focusing on the key nodes of the process. This study aims to fill this gap through studying the cross-border knowledge transfer process in NPD in MNCs.

\section{Methods}

This study adopts a qualitative method as few studies have been conducted to explore the knowledge transfer process. Through the qualitative study, I was able to track knowledge transfer activities and mechanisms across phases of NPD. A single-case study of CarInc was conducted. A single case can be particularly revealing with theoretical sampling to make theoretical contributions (Eisenhardt and Graebner 2007). In the automotive industry, due to product complexity and fierce market competition, effective cross-border knowledge transfer in NPD is essential for firms' competitive advantage. The company, CarInc, was chosen due to its effective knowledge transfer practices and high NPD performance.

\subsection{Research setting}

CarInc is a multinational automaker headquartered in the U.S. It sells products in North America, Europe, South America, and Asia Pacific. Its product lines include passenger cars (from small to large) and commercial vehicles. This study focuses on small and medium passenger cars, as this is an important product category in all national markets.

CarInc has a global R\&D organization. Its R\&D facilities are dispersed globally including the U.S., Germany, U.K., Brazil, and Australia. For small and medium cars, the German R\&D center was the lead center. The lead center was designated by the company headquarters based on its expertise. The lead center has the control over other R\&D centers. It has the global responsibility of NPD projects and coordinates NPD activities globally. Marketing and production departments are present in each region (North America, Europe, South America, and Asia Pacific). They are involved in NPD as well.

CarInc conducts globally coordinated NPD. It develops global cars for the global market (with some local modifications). Its NPD projects are a global effort with significant involvement of organizational units dispersed globally. Therefore, it provides an ideal context to study cross-border knowledge transfer.

CarInc is successful in cross-border knowledge transfer. This is evidenced by quality cars it has developed through global collaboration. These cars are among best-selling cars in most countries satisfying local market requirements. Therefore, studying CarInc is likely to generate interesting insights.

\subsection{Data collection}

The main data source is the semi-structured interviews with R\&D managers in CarInc. Data was collected in the 2013-2015 period. Overall, I conducted 21 interviews averaging one hour each. The interviews were conducted in the lead R\&D center and by telephone. During data collection, I focused on one recent past NPD project, the CD-Car project 
happened in 2010-2013. Meanwhile, I cross-checked other NPD projects and found that findings were consistent.

The main interview questions include: What is the NPD process? How was the CD-Car project conducted? What were the activities in each phase of NPD? How did organizational units collaborate globally? How was knowledge sharing facilitated across units? What is the role of the lead R\&D center? What is the role of headquarters? Interviews were recorded and transcribed for analysis. For each question, I interviewed multiple informants to reduce the bias, allowing data triangulation (Eisenhardt 1989; Yin 2009). The participants also shared some internal documents to help my understanding of the phenomenon. Also, I collected secondary data such as annual reports and news releases to help understand the company background and strategies. To mitigate the misinterpretation, at the end of the study I wrote the report and sent back to the company for review and feedback (Naget al. 2007).

\subsection{Data analysis}

Data were analyzed with the staged approach (Easterby-Smithet al. 2012). First, based on the NPD process phases (Table 1) mentioned above, I identified key activities within each phase in NPD of CarInc. This is also to familiarize with the data. Secondly, I analyzed how the globally distributed knowledge was transferred through these NPD activities in each phase. For example, for the concept development activities, the knowledge was transferred from local design centers to the lead R\&D center. At this stage, different knowledge flow patterns were identified across phases. Next, I analyzed how trust and understanding of cultural traits were facilitated in each phase of NPD. Several mechanisms were found. Finally, I analyzed the role of headquarters in facilitating trust. The HRM practices leveraged by headquarters contributed to effective cross-border knowledge transfer.

\section{The cross-border knowledge transfer process in NPD}

In this study, I found the mechanisms CarInc leveraged to promote cross-border knowledge transfer through trust and understanding of cultural traits in NPD activities. The main mechanism varied across the nodes of the process. The variance was caused by different NPD activities in different phases, each of which had a distinct knowledge flow pattern. Below I elaborate the knowledge transfer process in CarInc, focusing on the CD-Car project (but cross-checked with other projects as mentioned in Sect. 3.2). For each phase, I first describe the knowledge flow pattern as the background, and then explain how knowledge transfer was promoted (the mechanism) as main findings. The findings are summarized in Table 2.

\subsection{Product planning}

\subsubsection{Knowledge flow pattern}

In the product planning phase of NPD, the lead R\&D center organized the collection of local market requirements and new product ideas from marketing departments in all regions. Therefore, the knowledge flow was mainly from local marketing departments to the lead R\&D center (inflows). 


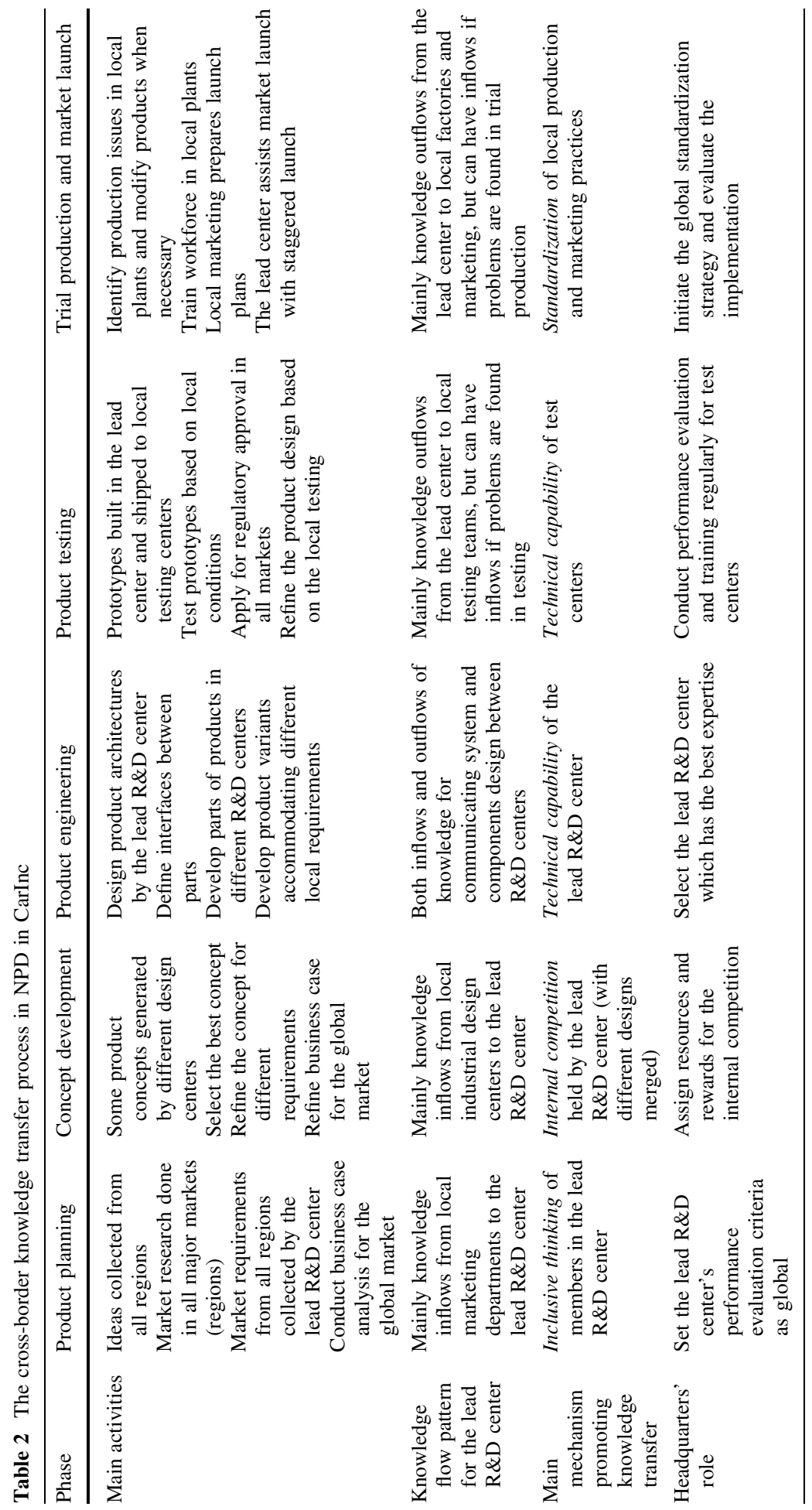


With operations experience, local marketing departments had accumulated abundant knowledge of local market requirements. For example, it was well known to local marketing that in America, a car should be powerful to appeal to customers while in Europe fuel-efficiency was deemed more important. In addition, for the NPD project, local marketing departments conducted market research for the targeted customer groups to be informed of local market trends. An R\&D manager explained:

Each region will look at the annual volumes and variants that will be sold, and develop the business plan for that vehicle ... The local team would start looking at designs, looking at demographics of whom they are going to sell the vehicle to ... The lead region [R\&D center] would start pulling together the information and then they would develop it.

Local marketing also provided new product ideas to the lead R\&D center. Product ideas are abstract product descriptions, often covering the most important features of products. An R\&D manager in the lead R\&D center offered an example of the product idea received from American marketing:

Target customer was the 20th to 30th year old single person, that had income of 60,000 to 70,000 dollars ... a car to a younger, more educated group.

Based on the new product ideas and local market requirements received, the lead R\&D center generated a detailed product plan and initiated the NPD project with clear objectives. One important task in this process was business case analysis (an analysis on whether the proposed product would be profitable). The lead center conducted business case analysis with market knowledge (e.g. expected sales volumes and market prices) provided by local marketing departments.

\subsubsection{Mechanism promoting knowledge transfer}

In this phase, inclusive thinking was the most important mechanism facilitating trust and understanding of cultural traits between the lead R\&D center and local marketing departments. As a result, cross-border knowledge transfer was promoted. Inclusive thinking means that organizational members fully consider conditions and opinions from all organizational units regardless of the geographic locations. It denotes the mindset of taking all members as one group with the same objective-success of the whole company.

In the NPD project, numerous local market requirements were collected including cost, handling, and fuel efficiency of the new car. The members in the lead R\&D center demonstrated inclusive thinking as they aimed at accommodating all these requirements (instead of only some of the requirements) when making the NPD project proposal, so as to make sure that the developed products would appeal to customers worldwide. They pushed themselves to overcome some trade-offs (such as powerfulness vs. fuel-efficiency) to some extent to serve the global market. An R\&D manager stated the mindset:

If it's a global project, it has to get input from all the market, that includes customer input ... 'cause they have, now meet the market conditions, or several global markets.

Similarly, the business case analysis was conducted in the lead R\&D center with all markets (instead of only some markets) in mind. The target market of the new product was defined as global from the beginning, which was another sign of inclusive thinking. 
Such inclusive thinking facilitated trust. With inclusive thinking, local marketing departments felt that they were part of the same group (even with different cultural traits) as their opinions were carefully considered by the lead R\&D center. In addition, they felt that the local markets would benefit from the new products developed by the lead R\&D center. An American marketing manager expressed the trust as a result of inclusive thinking and benefit for local markets:

I think the customers will appreciate that when they receive this as a good quality car. The design is globalized very much ... They tried to adjust things like suspension and seating and stuff like that to make Americans happy.

Therefore, local marketing departments actively communicated with the lead R\&D center to support the NPD project, and they understood each other's cultural traits (e.g. understanding of market requirements and work habits) in this process, which further strengthened trust.

\subsection{Concept development}

\subsubsection{Knowledge flow pattern}

In the concept development phase of NPD, product concepts (detailed drawing of the new product) were designed by several industrial design centers in different countries taking into account the local requirements. The lead R\&D center collected the design proposals from these design centers. Therefore, the knowledge flow was mainly from design centers to the lead R\&D center (inflows).

An R\&D manager explained the process:

Early phase ... it's relying on the design team, they are relying on the design team to understand and appreciate what the customer in that region is looking for, so they basically put together the themes [concepts].

After the lead R\&D center received product concepts from design centers, it selected the best one to focus on in the project. However, it also assimilated advantages of other concepts and merged with the selected concept. Such action ensured that the products would be suitable for sale in different regions.

\subsubsection{Mechanism promoting knowledge transfer}

To motivate knowledge sharing behaviors of design centers, the lead R\&D center organized an internal competition for product concepts. In this phase, internal competition was the main mechanism that promoted knowledge transfer. It contributed to trust and understanding of cultural traits in the process. An R\&D manager described the internal competition:

There is a design competition that's a really styling competition ... They would let each of the markets, major markets of their customer that they have a design center to make the design, styling proposal, and then they have competition that way and they choose the best styling from that.

The internal competition attracted design centers to participate, as winning the competition was regarded as an honor in the company. Financial reward was in place as well. The lead R\&D center did not simply select the best concept. Rather, it also used good 
elements of other concepts when making the final product design. This further motivated design centers to participate as they could see how they influenced the final design of the new product.

In the NPD project of CD-Car, the American design center won the competition, but the design proposals from other regions (Europe and Asia) were merged into the American design. The result was that the car had a muscular feeling (preferred Americans), but not too muscular to be accepted globally.

As design centers were motivated to participate in the competition, they had more intense communication with the lead $R \& D$ center. Such intense communication and the proactive attitude contributed to the mutual understanding of cultural traits (e.g. preference of car design). With more common understanding, trust was enhanced between organizational units.

\subsection{Product engineering}

\subsubsection{Knowledge flow pattern}

In the phase of product engineering in NPD, knowledge flow mainly happened between different $R \& D$ centers located in different countries. There were evident inflows to and outflows from the lead R\&D center, as shown by CarInc.

In CarInc, each R\&D center had technical advantages in certain fields, often certain parts of the product related to local requirements. For example, the Brazilian R\&D center had the best knowledge of flex-fuel engines due to local popularity of such engines; the British engine development center had the expertise of small, fuel-efficient engines suitable for European customers; the American R\&D center was good at powerful engines required in the U.S.; the German R\&D center was good at developing car bodies with high safety standards. Components were therefore developed in a specialized way. When developing specific components, these $R \& D$ centers needed to constantly exchange component design knowledge with each other to ensure that the components were compatible with each other.

With the product functions and appearances largely determined in early phases of NPD, in the product engineering phase, the lead (German) R\&D center defined the sub-systems to realize the proposed product functions and appearances. It then assigned development tasks of subsystems (or components) to other R\&D centers according to their expertise, which reflects specialization. The CD-Car project reflected wide collaboration across R\&D centers for product engineering, although the German lead center developed the majority of the car. For example, the Brazilian R\&D center worked on the flex-fuel engines, the British R\&D center worked on fuel-efficient engines, while the American R\&D center worked on powerful engines and automatic transmission systems. Also, the audio heads were developed in different centers. An R\&D manager mentioned:

Each vehicle has one lead product engineering setting ... Engine development is centralized according to the engine [types]. Region-specific systems are developed in the region and are generally released through one common point. The Audio head would be one example. They will vary by region since broadcast frequencies differ by region as well as customer preferences. 


\subsubsection{Mechanism promoting knowledge transfer}

In the product engineering phase of NPD, the technical capability of the lead R\&D center was the main mechanism promoting knowledge transfer. Technical capability of the lead $R \& D$ center brought trust of other $R \& D$ centers.

In this phase, the lead (German) R\&D center defined system-level design and assigned some components to be developed by other $R \& D$ centers, based on local expertise. It is widely recognized in the company that the German R\&D center had the best expertise in developing small cars, therefore, other R\&D centers felt that it could be trusted and relied on. These R\&D centers also wished to learn from the German center. An R\&D manager in the U.S. confirmed this through comparing a German car with an American car developed in the past:

I totally agree with that, that the European car, was better than the U.S. one [small car] ... The quality level of the U.S. car was not as good ... It wasn't a high performance for the solid engine.

Such technical trust enhanced communication and collaboration with the German R\&D center. Engineers actively contacted the German center to discuss components design to ensure compatibility. For instance, the engine development teams discussed with the German center about the space in the engine compartment of the car body and the power of the engine. The NPD teams in different R\&D centers leveraged both IT tools and site visits for communication. An R\&D manager in the U.S. recalled his experience: "When I was working on the CD-car program, you know, with the conference calls and trips back and forth between Europe and North America." Through intense communications of technical issues, they enhanced mutual understanding of cultural traits (e.g. work habits), thus building personal trust. It is technical trust that led to personal trust in this phase.

\subsection{Product testing}

\subsubsection{Knowledge flow pattern}

The lead R\&D center determined the functions and system design of the products, and possessed the whole product design drawings. It needed to share some technical details to the local test centers in order for them to conduct testing activities. Therefore, the knowledge flow was mainly outflow, but can have inflows depending on the situation at this stage.

In this phase, the product engineering work was largely finished, and the lead R\&D center produced the prototypes and shipped them to the local testing centers. This is because regulations and local environment (e.g. road condition and temperature) are different from country to country. Local test centers are more knowledgeable for these. An R\&D manager noted:

Each region is responsible for its own validation. The U.S. uses FMVSS and Europe uses ECE ... Prototype builds could occur in the lead region and then the samples shipped to the various regions to save tooling.

To perform the testing, the lead center needed to explain the functions and specifications of products to the local testing teams. There are numerous testing such as crash test, durability test, and emission test. If issues were identified, more technical details needed to 
be provided to find out the reason. There would be more knowledge inflows from local test centers regarding how to modify the design to pass the tests.

\subsubsection{Mechanism promoting knowledge transfer}

Technical capability of local test centers played a major role in shaping the trust so that the lead R\&D center was willing to share knowledge. Similarly, technical trust led to personal trust in this phase. An R\&D manager expressed the influence of technical capability:

The overall project has to deal with the different regulatory requirements for each of the markets ... There is gonna be validation and testing in all those places, because they are most capable of doing it.

With the positive attitude of the lead center, organizational members in different locations had a better understanding of cultural traits. As a result, when issues were identified from testing, engineers in test centers were willing to share knowledge with the lead R\&D center as well.

\subsection{Trial production and market launch}

\subsubsection{Knowledge flow pattern}

In the trial production and market launch phase, the local units (production and marketing) needed the support from the lead R\&D center to perform their tasks. For example, in trial production, the lead $R \& D$ center engineers helped to train local workers to familiarize the component design details and solve problems in production. Engineers from the lead R\&D center also explained product functions to local marketing teams. This phase of NPD was completed as the region-by-region basis, the so-called staggered launch. Therefore, in this phase, the knowledge flow was mainly outward from the lead R\&D center. An R\&D manager explained this process very clearly:

For trial production and market launch, [they were] handled individually by each market, however, with a staggered launch. The second market has the advantage of a smoother launch due to the lead market bearing the brunt of the launch issues, and so on for additional markets. So the overall global launch is a lot longer duration than a single local launch. Typically some key team members from the platform team move from market to market to support each local factory and market launch.

However, if there were issues identified in the trial production, there could be knowledge inflows to the lead $\mathrm{R} \& \mathrm{D}$ center from local production departments. The knowledge would help the lead R\&D center to resolve production issues.

\subsubsection{Mechanism promoting knowledge transfer}

In this phase, standardization of production and marketing practices was the key mechanism to enhance trust and thus promoting knowledge transfer. It means that practices were changed to be more similar globally, while not exactly the same. With globally coordinated $\mathrm{R} \& \mathrm{D}$, the lead $\mathrm{R} \& \mathrm{D}$ center pushed for standardized products (one global car with minor modifications for different countries) for high efficiency. It expected to see standardized production and marketing practices, because these could affect product design. An R\&D 
manager explained how different production equipment could lower product standardization:

The lifter was used to form part of the upper door. Theoretically, if you had to have the lifter $7 \mathrm{~mm}$ thicker, the door surface would have to move $7 \mathrm{~mm}$ to accommodate ... There were a number of issues that drove changes to the vehicle and tooling was one of them.

Production equipment was standardized in CarInc. The R\&D manager explained the reason: "A lot of tools are made in China now, versus 20 years ago we were using Italian tools here, and American tools in the U.S." The lead R\&D center regarded this as having the common goal (of standardization). Therefore, they had the trust to share knowledge with local production, and they understood cultural traits through the intense communication.

The situation was similar for marketing practices. With standardized marketing plan conveying the same message of a high-quality car globally, the lead R\&D center felt that its strategy was supported, therefore, it showed the trust in collaboration.

\section{The role of headquarters in cross-border knowledge transfer}

Additional findings are that the headquarters of CarInc played a critical role in supporting knowledge transfer in NPD. It leveraged HRM practices as administrative support to realize the key mechanisms identified above. These HRM practices are elaborated next.

In the product planning phase, the performance evaluation criteria set by headquarters contributed to the lead R\&D center's inclusive thinking. The performance evaluation criteria were set as global - the lead R\&D center (and its employees) was evaluated based on the global performance instead of the local performance. An executive noted: "They are responsible for the global applications of a globally developed plan." To achieve a high global performance in terms of sales volume, profit, and customer satisfaction, the lead R\&D center had to be supported by local marketing departments which understood local customers the most. It needed to earn the support through inclusive thinking.

In the concept development phase, headquarters allocated resources and rewards to support the internal competition. Costs were incurred in the competition in terms of, for example, traveling, setting competition criteria, organizing the committee. An R\&D manager commented: "It added a lot of cost to the development as well." These costs were covered by the headquarters as a means of support. Moreover, headquarters rewarded the design center which won the competition to motivate design centers to participate.

In the product engineering phase, the technical capability of the lead $R \& D$ center was actually determined by evaluation and selection practices done by headquarters in advance. Headquarters evaluated the technical capability of each R\&D center (and its employees), and selected one with the best expertise as the lead center. In this way, headquarters were playing a role in ensuring technical trust was in place. An executive noted: "To take a leadership role, an R\&D center must be superior to other centers in engineering."

Similarly, in the product testing phase, the technical capability of test centers was determined by regular performance evaluation practices by headquarters. Headquarters evaluated technical capability based on market feedback (whether customers' complaints on quality issues are linked to testing). Training was provided to enhance technical capability if necessary. 
In the trial production and market launch phase, standardization of production and marketing practices were actually a result of a company-wide global standardization strategy initiated by headquarters to enhance company's efficiency. An executive explained: "The standardization approach is applied throughout the entire company, including the cycle planning process, the manufacturing processes, the product development design guidelines that are used in order to develop new products." Headquarters also monitored all functions through performance evaluation (standardization as criteria) to ensure that the standardization strategy was well implemented.

\section{Discussion}

\subsection{Theoretical implications}

\subsubsection{Knowledge transfer}

In this study, through a process view, I discovered the dynamic pattern of knowledge transfer and the alternating nature of mechanisms, which have not been revealed in prior studies. In CarInc's NPD project, the firm first leveraged inclusive thinking, switched to internal competition, then leveraged technical capability, and finally changed to standardization. The alternating mechanisms facilitated trust and understanding of cultural traits.

Change of mechanisms was due to a number of factors: NPD activities, knowledge flow patterns, and involved functions (types of knowledge). In product planning and concept development phases, it was mainly knowledge inflows to the lead R\&D center, therefore, the motivation of local marketing departments and design centers to share was the key. Due to different nature of tasks, the technical capability would not be effective in facilitating trust of marketing departments and design centers. Inclusive thinking (satisfying local markets) and internal competition (choosing the best concept but merging other concepts) fit with tasks in marketing departments (dealing with market issues) and design centers (dealing with both market and technical issues), thus bringing motivation to share. For product engineering and product testing, $R \& D$ centers and test centers were doing similar tasks handling technical issues, thus technical capability could significantly affect trust. For trial production and market launch, production and marketing departments were doing tasks different in nature from ones in R\&D centers, so technical capability would not be effective. As it was mainly knowledge outflow from the lead R\&D center, the motivation of the lead R\&D center was the key. Standardization of practices in production and marketing departments could motivate the lead $R \& D$ to share. Therefore, this study shows the contingent nature of the mechanisms, and certain contingent factors (NPD activities, knowledge flow patterns, and involved functions) are identified, which is another contribution to the literature.

Gupta and Govindarajan (1991) analyzed different roles of subsidiaries in MNCs based on knowledge flows. In this study, I found the role variation across functions. More importantly, I reveal the dynamic nature of the roles due to changed knowledge flows. For the lead R\&D center, it changed from inflow to outflow (from implementer to innovator), whereas marketing departments changed from outflow to inflow (from innovator to implementer). This is because NPD can be regarded as a knowledge processing task. Market knowledge can be deemed as raw material, while technical knowledge (and 
developed products) can be considered as goods. MNCs transform new product ideas based on market requirements into developed products through NPD. The implication drawn here is that the interaction between organizational units and its influence on the flow of knowledge should be taken into account in MNCs research.

\subsubsection{HRM practices}

This study emphasizes the importance of performance evaluation and reward in facilitating trust between organizational units. Although performance evaluation and reward can help to realize different mechanisms, they need to be leveraged differently (e.g. different criteria for evaluation). For example, to have inclusive thinking, the evaluation criteria should be global performance; to have standardization practices, the evaluation criteria of standardization need to be added.

Minbaeva (2005) shows that HRM practices of staffing, performance appraisal, reward system, and career management can contribute to knowledge transfer. This study indicates that while these practices may all contribute to employees' absorptive capacity, it is performance evaluation and reward that mainly contribute to trust. In other words, staffing and career management would have less effect on trust. Performance evaluation and reward can shape employees' motivation to actively communicate and collaborate across borders (as shown in this study) more than staffing and career management can do. This is partly because performance evaluation can be very flexible including certain criteria to fit with the context (activity) as mentioned above.

Bjorkmanet al. (2004) through analyzing headquarters' role found that performance evaluation and reward contribute to outward knowledge transfer. This study suggests that performance evaluation and reward can affect both inward and outward knowledge transfer, as knowledge transfer (and trust) denotes interaction between organizational units. The evaluation criteria may vary for inward and outward knowledge transfer.

\subsubsection{Global NPD in MNCs}

Relatively fewer studies have explored challenges of knowledge transfer in NPD in the global context. These studies mainly focused on tacitness of knowledge (Kleinschmidtet al. 2007; Subramaniam and Venkatraman 2001), and more studies are needed focusing on trust. In this study, I found that the global context can complicate knowledge transfer, as MNCs face the challenge of both cross-functional collaboration and geographic distance. MNCs need to have mechanisms in place to facilitate trust overcoming the negative effect of geographic distance. Functions involved in a phase determine which mechanism to leverage. The cross-functional nature of NPD causes the variety of mechanisms leveraged. In other words, the mechanisms discovered in this study are a result of both geographic distance and cross-functional collaboration in NPD.

\subsection{Managerial implications}

This study can draw implications for practices in several ways. First, firms should leverage the mechanisms to promote knowledge transfer discovered in a flexible way, because it is not likely that one mechanism can work in all conditions. For example, in an NPD project, different mechanisms should be adopted due to different activities across NPD phases. Therefore, firms should identify different operational activities, and design mechanisms 
accordingly. Firms should evaluate and monitor the effects of the implemented mechanisms, as this can be a trial-and-error process over time. Once firms find effective mechanisms (e.g. internal competition) promoting knowledge transfer for certain operational activities (e.g. concept development), firms should institutionalize them (e.g. changing policies or evaluation criteria accordingly) to make sure they can be implemented at the right time.

In addition, trust is a critical factor for knowledge transfer, and it is linked to an understanding of cultural traits. Training is often used in firms to enhance understanding of different cultures. However, training could not facilitate trust directly. The proactive attitude for communication and collaboration is the key to both trust and understanding of cultural traits. Headquarters could facilitate the proactive attitude through certain HRM practices as shown in this study. Performance evaluation is the most important HRM practice in this regard, as it can affect employees' motivations. As headquarters are not familiar with specific operational activities, it should not intervene subsidiaries' activities directly. Setting performance evaluation criteria is the best way to impact subsidiaries in this regard.

\section{Conclusion}

This study explores the cross-border knowledge transfer process in NPD activities in MNCs. Through the case study of CarInc, I found different mechanisms promoting crossborder knowledge transfer: inclusive thinking, internal competition, technical capability, and standardization. I reveal the alternating nature of the mechanisms along NPD phases. The headquarters played an important role in facilitating cross-border knowledge transfer through HRM practices. Performance evaluation as an important practice was leveraged differently across NPD phases to realize these mechanisms.

Open Access This article is distributed under the terms of the Creative Commons Attribution 4.0 International License (http://creativecommons.org/licenses/by/4.0/), which permits unrestricted use, distribution, and reproduction in any medium, provided you give appropriate credit to the original author(s) and the source, provide a link to the Creative Commons license, and indicate if changes were made.

\section{References}

Andersson, U., Dasi, A., Mudambi, R., \& Pedersen, T. (2016). Technology, innovation and knowledge: The importance of ideas and international connectivity. Journal of World Business, 51(1), 153-162.

Appeldorn, R. H. (1997). Technology transfer in a diversified, global manufacturing company. The Journal of Technology Transfer, 22(3), 57-63.

Barczak, G., \& McDonough, E. F. (2003). Leading global product development teams. Research-Technology Management, 46(6), 14-18.

Bartlett, C. A., \& Ghoshal, S. (2000). Transnational management: Text, cases, and readings in cross-border management (3rd ed.). Boston: Irwin McGraw-Hill.

Bierly, P. E., III, Stark, E. M., \& Kessler, E. H. (2009). The moderating effects of virtuality on the antecedents and outcome of NPD team trust. Journal of Product Innovation Management, 26(5), $551-565$.

Bjorkman, I., Barner-Rasmussen, W., \& Li, L. (2004). Managing knowledge transfer in MNCs: The impact of headquarters control mechanisms. Journal of International Business Studies, 35(5), 443-455.

Buckley, P. J., Clegg, J., \& Tan, H. (2006). Cultural awareness in knowledge transfer to China-the role of guanxi and mianzi. Journal of World Business, 41(3), 275-288. 
Carlile, P. R. (2002). A pragmatic view of knowledge and boundaries: Boundary objects in new product development. Organization Science, 13(4), 442-455.

Castellano, S., Davidson, P., \& Khelladi, I. (2017). Creativity techniques to enhance knowledge transfer within global virtual teams in the context of knowledge-intensive enterprises. The Journal of Technology Transfer, 42(2), 253-266.

Cavaliere, V., \& Lombardi, S. (2015). Exploring different cultural configurations: How do they affect subsidiaries' knowledge sharing behaviors? Journal of Knowledge Management, 19(2), 141-163.

Cavaliere, V., Lombardi, S., \& Giustiniano, L. (2015). Knowledge sharing in knowledge-intensive manufacturing firms. An empirical study of its enablers. Journal of Knowledge Management, 19(6), 1124-1145.

Clark, K. B., \& Fujimoto, T. (1991). Product development performance: Strategy, organization, and management in the world auto industry. Boston: Harvard Business School Press.

Cooper, R. G., \& Kleinschmidt, E. J. (1986). An investigation into the new product process: Steps, deficiencies, and impact. Journal of Product Innovation Management, 3(2), 71-85.

Dhanaraj, C., Lyles, M. A., Steensma, H. K., \& Tihanyi, L. (2004). Managing tacit and explicit knowledge transfer in IJVs: The role of relational embeddedness and the impact on performance. Journal of International Business Studies, 35(5), 428-442.

Easterby-Smith, M., Thorpe, R., \& Jackson, P. R. (2012). Management research. London: Sage.

Eisenhardt, K. M. (1989). Building theories from case study research. Academy of Management Review, 14(4), 532-550.

Eisenhardt, K. M., \& Graebner, M. E. (2007). Theory building from cases: Opportunities and challenges. Academy of Management Journal, 50(1), 25-32.

Eppinger, S. D., \& Chitkara, A. R. (2006). The new practice of global product development. MIT Sloan Management Review, 47(4), 22-30.

Ghemawat, P. (2001). Distance still matters. The hard reality of global expansion. Harvard Business Review, 79(8), 137-147.

Ghoshal, S., \& Bartlett, C. A. (1988). Creation, adoption, and diffusion of innovations by subsidiaries of multinational corporations. Journal of International Business Studies, 19(3), 365-388.

Gupta, A. K., \& Govindarajan, V. (1991). Knowledge flows and the structure of control within multinational corporations. Academy of Management Review, 16(4), 768-792.

Gupta, A. K., \& Govindarajan, V. (2000). Knowledge flows within multinational corporations. Strategic Management Journal, 21(4), 473-496.

Haas, M. R., \& Cummings, J. N. (2015). Barriers to knowledge seeking within MNC teams: Which differences matter most? Journal of International Business Studies, 46(1), 36-62.

Holland, S., Gaston, K., \& Gomes, J. (2000). Critical success factors for cross-functional teamwork in new product development. International Journal of Management Reviews, 2(3), 231-259.

Hong, J. F. L., \& Nguyen, T. V. (2013). Local knowledge acquisition of foreign subsidiaries in Vietnam and China. Multinational Business Review, 21(4), 312-333.

Javidan, M., Stahl, G. K., Brodbeck, F., \& Wilderom, C. P. M. (2005). Cross-border transfer of knowledge: Cultural lessons from project globe. Academy of Management Executive, 19(2), 59-76.

Kahn, K. B., \& McDonough, E. F., III. (1997). An empirical study of the relationships among co-location, integration, performance, and satisfaction. Journal of Product Innovation Management, 14(3), $161-178$.

Karagozoglu, N., \& Brown, W. B. (1993). Time-based management of the new product development process. Journal of Product Innovation Management, 10(3), 204-215.

Kasper, H., Lehrer, M., Muhlbacher, J., \& Muller, B. (2013). On the different "worlds" of intra-organizational knowledge management: Understanding idiosyncratic variation in MNC cross-site knowledgesharing practices. International Business Review, 22(1), 326-338.

Kleinschmidt, E. J., de Brentani, U., \& Salomo, S. (2007). Performance of global new product development programs: A resource-based view. Journal of Product Innovation Management, 24(5), 419-441.

Kleinschmidt, E. J., de Brentani, U., \& Salomo, S. (2010). Information processing and firm-internal environment contingencies: Performance impact on global new product development. Creativity \& Innovation Management, 19(3), 200-218.

Kotabe, M., Dunlap-Hinkler, D., Parente, R., \& Mishra, H. A. (2007). Determinants of cross-national knowledge transfer and its effect on firm innovation. Journal of International Business Studies, 38(2), 259-282.

Li, L. (2005). The effects of trust and shared vision on inward knowledge transfer in subsidiaries' intra-and inter-organizational relationships. International Business Review, 14(1), 77-95. 
McDonough, E. F., III, Kahn, K. B., \& Barczak, G. (2001). An investigation of the use of global, virtual, and colocated new product development teams. Journal of Product Innovation Management, 18(2), $110-120$.

Michailova, S., \& Bernhard Nielsen, B. (2006). MNCs and knowledge management: A typology and key features. Journal of Knowledge Management, 10(1), 44-54.

Minbaeva, D. B. (2005). Hrm practices and MNC knowledge transfer. Personnel review, 34(1), $125-144$.

Minbaeva, D. B. (2007). Knowledge transfer in multinational corporations. Management International Review (MIR), 47(4), 567-593.

Minbaeva, D. B. (2008). Hrm practices affecting extrinsic and intrinsic motivation of knowledge receivers and their effect on intra-MNC knowledge transfer. International Business Review, 17(6), 703-713.

Minbaeva, D. B., Pedersen, T., Björkman, I., Fey, C. F., \& Park, H. J. (2003). MNC knowledge transfer, subsidiary absorptive capacity, and HRM. Journal of International Business Studies, 34(6), 586-599.

Moenaert, R. K., \& Souder, W. E. (1990). An information transfer model for integrating marketing and R\&D personnel in new product development projects. Journal of Product Innovation Management, 7(2), 91-107.

Monplaisir, L., Malikane, C., \& Ojah, K. (2009). Strategic competition, valuation, costs and growth potential: The example of global product design and development. Multinational Business Review, 17(1), 47-71.

Monteiro, L. F., Arvidsson, N., \& Birkinshaw, J. (2008). Knowledge flows within multinational corporations: Explaining subsidiary isolation and its performance implications. Organization Science, 19(1), 90-107.

Nag, R., Corley, K. G., \& Gioia, D. A. (2007). The intersection of organizational identity, knowledge, and practice: Attempting strategic change via knowledge grafting. Academy of Management Journal, 50(4), 821-847.

Noorderhaven, N., \& Harzing, A.-W. (2009). Knowledge-sharing and social interaction within MNEs. Journal of International Business Studies, 40(5), 719-741.

Rafii, F. (1995). How important is physical collocation to product development success? Business Horizons, 38(1), 78-84.

Reagans, R., \& McEvily, B. (2003). Network structure and knowledge transfer: The effects of cohesion and range. Administrative Science Quarterly, 48(2), 240-267.

Salomo, S., Kleinschmidt, E. J., \& de Brentani, U. (2010). Managing new product development teams in a globally dispersed NPD program. Journal of Product Innovation Management, 27(7), 955-971.

Sarala, R. M., \& Vaara, E. (2010). Cultural differences, convergence, and crossvergence as explanations of knowledge transfer in international acquisitions. Journal of International Business Studies, 41(8), 1365-1390.

Scalera, V. G., Mukherjee, D., Perri, A., \& Mudambi, R. (2014). A longitudinal study of MNE innovation: The case of Goodyear. Multinational Business Review, 22(3), 270-293.

Schilling, M. A., \& Hill, C. W. L. (1998). Managing the new product development process: Strategic imperatives. Academy of Management Executive, 12(3), 67-81.

Schlegelmilch, B. B., \& Chini, T. C. (2003). Knowledge transfer between marketing functions in multinational companies: A conceptual model. International Business Review, 12(2), 215-232.

Sherman, J. D., Berkowitz, D., \& Souder, W. E. (2005). New product development performance and the interaction of cross-functional integration and knowledge management. Journal of Product Innovation Management, 22(5), 399-411.

Song, X. M., Neeley, S. M., \& Zhao, Y. (1996). Managing R\&D-marketing integration in the new product development process. Industrial Marketing Management, 25(6), 545-553.

Song, X. M., \& Parry, M. E. (1997). A cross-national comparative study of new product development processes: Japan and the United States. Journal of Marketing, 61(2), 1-18.

Sosa, M. E., Eppinger, S. D., Pich, M., McKendrick, D. G., \& Stout, S. K. (2002). Factors that influence technical communication in distributed product development: An empirical study in the telecommunications industry. IEEE Transactions on Engineering Management, 49(1), 45-58.

Souder, W. E. (1988). Managing relations between R\&D and marketing in new product development projects. Journal of Product Innovation Management, 5(1), 6-19.

Subramaniam, M. (2006). Integrating cross-border knowledge for transnational new product development. Journal of Product Innovation Management, 23(6), 541-555.

Subramaniam, M., Rosenthal, S. R., \& Hatten, K. J. (1998). Global new product development processes: Preliminary findings and research propositions. Journal of Management Studies, 35(6), 773-796.

Subramaniam, M., \& Venkatraman, N. (2001). Determinants of transnational new product development capability: Testing the influence of transferring and deploying tacit overseas knowledge. Strategic Management Journal, 22(4), 359-378. 
Taschler, D. R., \& Chappelow, C. C. (1997). Intra-company technology transfer in a multinational industrial firm. The Journal of Technology Transfer, 22(1), 29-34.

Tavcar, J., Zavbi, R., Verlinden, J., \& Duhovnik, J. (2005). Skills for effective communication and work in global product development teams. Journal of Engineering Design, 16(6), 557-576.

Ulrich, K. T., \& Eppinger, S. D. (2012). Product design and development (5th ed.). New York: McGrawHill.

van Dijk, A., Hendriks, P., \& Romo-Leroux, I. (2016). Knowledge sharing and social capital in globally distributed execution. Journal of Knowledge Management, 20(2), 327-343.

Yin, R. K. (2009). Case study research: Design and methods (4th ed.). Los Angeles, CA: Sage. 